\title{
Two Clerodane Diterpenes and Flavonoids from Croton brasiliensis
}

\author{
Sebastião F. Palmeira Jr. ${ }^{a}$, Lucia M. Conserva ${ }^{*, a}$ and Edilberto R. Silveira ${ }^{b}$ \\ ${ }^{a}$ Departamento de Química, Universidade Federal de Alagoas, 57072-970 Maceió-AL, Brazil \\ ${ }^{b}$ Departamento de Química Orgânica e Inorgânica, Universidade Federal do Ceará, \\ 60021-970 Fortaleza-CE, Brazil
}

\begin{abstract}
Dois novos diterpenos do tipo clerodano, crotobrasilina A e crotobrasilina $\mathrm{B}$, foram isolados juntamente com quatro 3-metoxiflavonas conhecidas: casticina, penduletina, crisosplenol-D e artemetina, das folhas e caule de Croton brasiliensis. A elucidação estrutural destes compostos foi feita com base na análise dos dados espectroscópicos, especialmente RMN, incluindo técnicas bidimensionais (COSY, HMQC, HMBC e NOESY).
\end{abstract}

Two new clerodane diterpenes, crotobrasilin A and crotobrasilin B, were isolated in addition to four known 3-methoxyflavones: casticin, penduletin, chrysosplenol-D and artemetin from leaves and stems of Croton brasiliensis. The structural elucidation of these compounds was made on the basis of spectroscopic data analyses, especially NMR, including 2D techniques (COSY, HMQC, HMBC and NOESY).

Keywords: Croton brasiliensis, clerodane diterpenes, 3-methoxyflavones

\section{Introduction}

The genus Croton (Euphorbiaceae), which comprises about 700 species, is widely distributed in all regions of Brazil. ${ }^{1}$ Many of these species are known in the Brazilian Northeast region as 'capixingui' and 'marmeleiro" and have been used in folk medicine for a large number of applications. ${ }^{2}$ Previous phytochemical investigations show that this genus possess alkaloids, ${ }^{2}$ flavonoids, ${ }^{3-6}$ triterpenoids, ${ }^{4,7,8}$ and a large number of diterpenoids. ${ }^{5,6,9-11}$ In this paper, we report the isolation and structural elucidation of two new clerodane diterpenes and four known 3-methoxyflavones from leaves and stems of $C$. brasiliensis Mull. Arg.

\section{Results and Discussion}

The dichloromethane extracts from leaves and stems of $C$. brasiliensis after chromatography fractionation and recrystallizations afforded two clerodane diterpenes (1-2) in addition to four known 3-methoxyflavones (3-6).

Compound 1, isolated as a white amorphous powder, mp 198.5-201.4 ${ }^{\circ} \mathrm{C}$, by EIMS showed a molecular ion at $m / z$ 416. This information, along with NMR data,

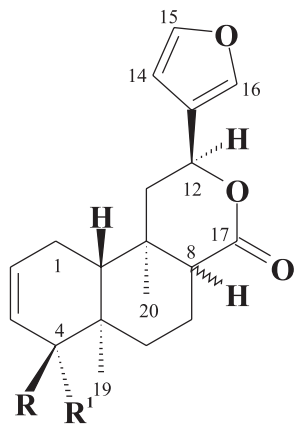

$1 \mathrm{R}=\mathrm{CO}_{2} \mathrm{Me}, \mathrm{R}^{1}=\mathrm{OAc} 8 \beta, \mathrm{H}$
$2 \mathrm{R}=\mathrm{OH}, \mathrm{R}^{1}=\mathrm{CO}_{2} \mathrm{Me}, 8 \alpha, \mathrm{H}$
$7 \mathrm{R}=\mathrm{CO}_{2} \mathrm{Me}, \mathrm{R}^{1}=\mathrm{OH}, 8 \alpha, \mathrm{H}$$$
7 \mathrm{R}=\mathrm{CO}_{2} \mathrm{Me}, \mathrm{R}^{1}=\mathrm{OH}, 8 \alpha, \mathrm{H}
$$<smiles>CC(=O)C[C@]1(O)C=CC[C@H]2[C@@H]3CC[C@H]4C(=O)O[C@H](c5ccoc5)C[C@H]4[C@H]3C[C@H]21</smiles>

8<smiles>[R]c1ccc(-c2oc3cc(OC)c(OC)c(O)c3c(=O)c2OC)cc1[R]</smiles>

$3 \mathrm{R}=\mathrm{OH}, \mathrm{R}^{1}=\mathrm{OMe}$

$4 \mathrm{R}=\mathrm{H}, \mathrm{R}^{1}=\mathrm{OH}$

$5 \mathrm{R}=\mathrm{R}^{1}=\mathrm{OMe}$

$6 \mathrm{R}=\mathrm{R}^{1}=\mathrm{OH}$ 
suggested $\mathrm{C}_{23} \mathrm{H}_{28} \mathrm{O}_{7}$ as the molecular formula, in accordance with the observed molecular weight. The FTIR spectrum indicated the presence of ester and lactone carbonyls $\left(1734 \mathrm{~cm}^{-1}\right), \beta$-substituted furan ring (1490 and $\left.816 \mathrm{~cm}^{-1}\right)$, and double bond $\left(1665 \mathrm{~cm}^{-1}\right)$. The ${ }^{13} \mathrm{C}$ NMR spectra (CPD, DEPT and HMQC) showed 23 carbon signals (four methyls, four methylenes, eight methines, and seven non-hydrogenated), consistent with substituted diterpene skeleton. The NMR spectra, including ${ }^{1} \mathrm{H}-{ }^{-1} \mathrm{H}$ COSY, NOESY, HMQC and HMBC, showed signals for a cis-disubstituted double bond $\left[\delta_{\mathrm{H}} 5.81(\mathrm{~m}, \mathrm{H}-2)\right.$ and $6.40(\mathrm{~d}, J 10.3 \mathrm{~Hz}, \mathrm{H}-3) ; \delta_{\mathrm{C}} 131.1(\mathrm{C}-2)$ and $125.9(\mathrm{C}-3)$ ], a $\beta$-substituted furan ring $\left[\delta_{\mathrm{H}} 6.21\right.$ (br s, H-14), 7.15 (br s, $\mathrm{H}-16)$ and 7.16 (br s, H-15); $\delta_{\mathrm{C}} 109.4$ (C-14), 126.7 (C13), 139.9 (C-16) and 144.0 (C-15)], two angular methyl groups $\left[\delta_{\mathrm{H}} 0.80(\mathrm{~s}, \mathrm{Me}-20)\right.$ and $1.13(\mathrm{~s}, \mathrm{Me}-19) ; \delta_{\mathrm{C}} 15.6$ (Me-20) and 16.8 (Me-19)], a carbonyl methyl ester group $\left[\delta_{\mathrm{H}} 3.49(\mathrm{~s}, \mathrm{OMe}) ; \delta_{\mathrm{C}} 52.4(\mathrm{OMe})\right.$ and $\left.170.6(\mathrm{C}-18)\right]$, and signals for an acetyl group $\left[\delta_{\mathrm{H}} 1.80(\mathrm{~s}) ; \delta_{\mathrm{C}} 21.4\right.$ and 170.3], whose correlations observed in the HMBC spectrum (Figure 1$)$, specially for $\mathrm{H}-6_{\mathrm{ax}}(\delta 1.37), \mathrm{H}-10(\delta 1.94)$, and Me-19 $(\delta$ 1.13) with C-4 $(\delta$ 87.8) defined its position in this carbon. Moreover, also were observed signals for $\mathrm{sp}^{3}$ oxymethine carbon $\left[\delta_{\mathrm{H}} 5.06(\mathrm{dd}, J 5.1\right.$ and $11.6 \mathrm{~Hz}$, $\mathrm{H}-12) ; \delta_{\mathrm{C}} 71.7$ (C-12)], which chemical shifts and multiplicities are characteristic of hydrogen attached to a carbon involved in a $\delta$-lactone moiety $\left[\delta_{\mathrm{C}} 171.0\right.$ (C-17)]. Correlations observed in the HMBC spectrum (Figure 1) between H-12 $(\delta$ 5.06) and C-13 $(\delta$ 126.7), C-14 $(\delta$ 109.4), and C-16 ( $\delta$ 139.9) evidenced the relationship between the furan ring and $\delta$-lactone moiety. The remaining NMR data showed characteristic chemical shifts for two methines, four methylenes, and three nonhydrogenated carbons (Table 1). Thus, on the basis in the evidence of the spectral data and comparison with those reported for cordatin (7) and epi-cordatine

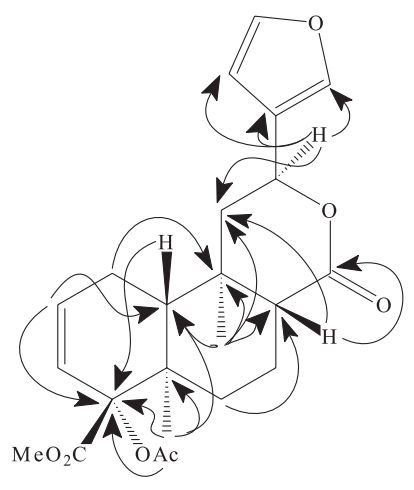

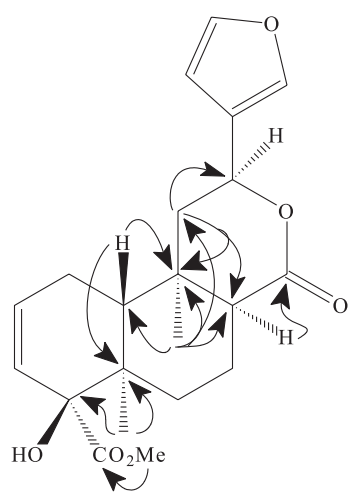

2
Figure 1. Selected HMBC correlations for $\mathbf{1}$ and 2.
(8), two $\beta$-furan clerodane diterpenes isolated from Aparisthmium cordatum ${ }^{12}$ and Burasia madagascarensis,${ }^{13}$ respectively, structure of a $\beta$-furan clerodane diterpene was proposed.

NOESY experiment deduced the relative configurations at asymmetric centers (Figure 2). Dipolar-dipolar correlations between $\mathrm{H}-12(\delta 5.06)$ and Me-20 $(\delta 0.80)$, and this later with Me-19 $(\delta 1.13)$, as well as for $\mathrm{H}-6_{\mathrm{ax}}(\delta 1.37)$ and H-8 $(\delta 1.73)$ with $\mathrm{H}-10(\delta 1.94)$ demonstrated a 1,3-cis relationship among these hydrogens and suggested that $\mathbf{1}$ have $\mathrm{A} / \mathrm{B}$ and $\mathrm{B} / \mathrm{C}$ trans ring junctions. These relative configurations were also supported by comparison of the NMR data of 1 , exactly when recorded also in $\mathrm{CDCl}_{3}$, with those of 7, whose structure was determined by $\mathrm{X}$-rays diffraction analysis and possess $\mathrm{A} / \mathrm{B}$ trans and $\mathrm{B} / \mathrm{C}$ cis ring junctions. In particular, compound $\mathbf{1}$ exhibited significant differences in the chemical shifts of C-8, C-11, and $\mathrm{C}-17$ and showed signals for $\mathrm{H}-8, \mathrm{H}-10$ and $\mathrm{H}-11$ at upfield (Table 1). These differences in the chemical shifts these hydrogens can be explained if ring $\mathrm{C}$ to adopt a skew-boat conformation, with the ring furan in $\beta$-equatorial. Thus, compound $\mathbf{1}$, named here crotobrasilin A, was proposed to be the $(5 \mathrm{R}, 8 \mathrm{R}, 9 \mathrm{R}, 10 \mathrm{R})-4 \mathrm{R}$-acetoxy-15,16epoxy-neo-cleroda-2,13(16),14-trien-17,12S-olide-18oate methyl.

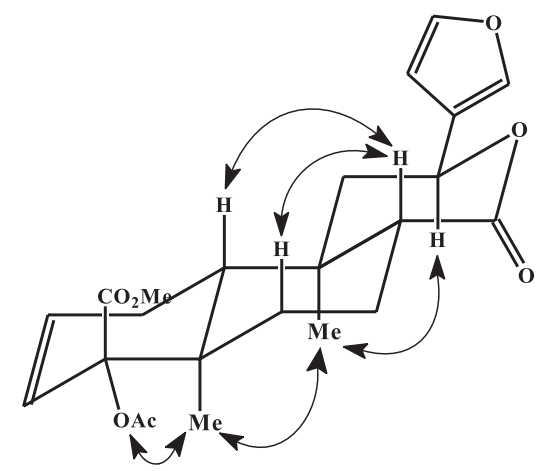

Figure 2. Significant NOESY correlations of $\mathbf{1}$.

Compound 2 was isolated as yellowish oil, in a mixture with $\mathbf{1}$. Due to the small quantity of the mixture, we have not attempted to separate both compounds in order to avoid any loss of material. However, its NMR data were discernable since furnished different intensities of the signals for both compounds [ratio 2.5:1 (2): (1)]. So, all assignments of the chemical shifts for 2 were inferred (Table 1). In a similar way that compound $\mathbf{1}$, the NMR spectral data of $\mathbf{2}$ also showed signals for a $\beta$ substituted furan ring $\left[\delta_{\mathrm{H}} 6.48\right.$ (br s, H-14), 7.47 (br s, H15) and 7.53 (br s, H-16); $\delta_{\mathrm{C}} 109.9$ (C-14), 125.2 (C-13), 141.0 (C-16) and 144.9 (C-15)], a cis-disubstituted double bond $\left[\delta_{\mathrm{H}} 5.99(\mathrm{~m}, \mathrm{H}-2)\right.$ and $5.37(\mathrm{~d}, J 9.4 \mathrm{~Hz}, \mathrm{H}-$ 
Table 1. NMR data $\left({ }^{1} \mathrm{H}: 500 ;{ }^{13} \mathrm{C}: 125 \mathrm{MHz}, J\right.$ in $\left.\mathrm{Hz}\right)$ for compounds $\mathbf{1}\left(\mathrm{C}_{6} \mathrm{D}_{6}\right), \mathbf{2}\left(\mathrm{CDCl}_{3}\right)$, and the models 7 and $\mathbf{8}\left(\mathrm{CDCl}_{3}\right)$

\begin{tabular}{|c|c|c|c|c|c|c|c|c|}
\hline \multirow[b]{2}{*}{ Position } & \multicolumn{2}{|c|}{$\mathbf{1}^{\mathrm{a}}$} & \multicolumn{2}{|c|}{$2^{\mathrm{a}}$} & \multicolumn{2}{|c|}{$7^{12}$} & \multicolumn{2}{|r|}{$8^{13}$} \\
\hline & $\delta_{\mathrm{C}}$ & $\delta_{\text {н }}$ & $\delta_{\mathrm{c}}$ & $\delta_{\text {н }}$ & $\delta_{\mathrm{c}}$ & $\delta_{\text {н }}$ & $\delta_{\mathrm{C}}$ & $\delta_{\text {н }}$ \\
\hline $1_{\text {ax }}$ & 23.9 & $1.77 \mathrm{~m}$ & 19.1 & $2.18 \mathrm{~m}$ & $17.6^{\mathrm{b}}$ & $2.14 \mathrm{~m}$ & 25.9 & $1.96 \mathrm{~m}$ \\
\hline $1_{\mathrm{eq}}$ & & $1.64 \mathrm{~m}$ & & $1.84(t, 7.6)$ & & $2.06 \mathrm{~m}$ & & $2.24 \mathrm{~m}$ \\
\hline 2 & 131.1 & $5.81 \mathrm{~m}$ & 131.4 & $5.99 \mathrm{~m}$ & 123.2 & $5.90 \mathrm{~m}$ & 129.6 & $5.94(\mathrm{ddd}, 9.9 ; 4.7 ; 2.7)$ \\
\hline 3 & 125.9 & $6.40(\mathrm{~d}, 10.3)$ & 129.7 & $5.37(\mathrm{~d}, 9.4)$ & 129.9 & $5.35(\mathrm{~d}, 10)$ & 125.2 & $5.62 \mathrm{~m}$ \\
\hline 4 & 87.8 & & 82.1 & & 80.5 & & 78.4 & \\
\hline 5 & 40.7 & & 41.9 & & 40.4 & & 40.9 & \\
\hline $6_{\mathrm{ax}}$ & 33.9 & $1.37(\mathrm{dd}, 3.5 ; 13.4)$ & 29.8 & $1.46 \mathrm{~m}$ & 28.3 & $1.44 \mathrm{~m}$ & 27.2 & $1.61(\mathrm{ddd}, 13.3 ; 13.4 ; 5.0)$ \\
\hline $6_{\text {eq }}$ & & $1.99 \mathrm{~m}$ & & $1.67 \mathrm{~m}$ & & - & & $1.32 \mathrm{~m}$ \\
\hline $7_{a x}$ & 19.2 & $1.64 \mathrm{~m}$ & 24.4 & $1.87 \mathrm{~m}$ & $22.9^{\mathrm{b}}$ & $1.83 \mathrm{~m}$ & 23.0 & $1.86 \mathrm{~m}$ \\
\hline $7_{\text {eq }}^{\text {ax }}$ & & $2.28 \mathrm{~m}$ & & $2.18 \mathrm{~m}$ & & $2.10 \mathrm{~m}$ & & $1.97 \mathrm{~m}$ \\
\hline 8 & 51.8 & $1.73 \mathrm{~m}$ & 46.2 & $2.52 \mathrm{~m}$ & 44.7 & $2.32(\mathrm{dd}, 5 ; 12)$ & 44.7 & $2.61(\mathrm{dd}, 13.4 ; 6.2)$ \\
\hline 9 & 36.6 & & 36.8 & & 35.3 & & 35.0 & \\
\hline 10 & 44.6 & $1.94(\mathrm{dd}, 5.3 ; 11.1)$ & 46.1 & $2.35(\mathrm{dd}, 4.8 ; 10.8)$ & 44.5 & $2.49 \mathrm{~m}$ & 40.6 & $2.10(\mathrm{dd}, 10.6 ; 6.4)$ \\
\hline $11_{\text {ax }}$ & 44.5 & $1.30(\mathrm{t}, 12.5)$ & 50.2 & $1.84(\mathrm{t}, 7.6)$ & 48.7 & $1.80(\mathrm{dd}, 5 ; 12)$ & 41.6 & $1.82(\mathrm{dd}, 15.4 ; 12.5)$ \\
\hline $11_{\mathrm{eq}}^{\mathrm{ax}}$ & & $1.64 \mathrm{~m}$ & & $2.08 \mathrm{~m}$ & & $2.01(\mathrm{dd}, 3 ; 12)$ & & $2.46(\mathrm{dd}, 15.4 ; 5.1)$ \\
\hline $12^{\mathrm{eq}}$ & 71.7 & $5.06(\mathrm{dd}, 5.1 ; 11.6)$ & 71.2 & $5.31(\mathrm{dd}, 5.5 ; 13.5)$ & 69.7 & $5.20(\mathrm{dd}, 3 ; 12)$ & 70.8 & $5.65(\mathrm{dd}, 12.5 ; 5.1)$ \\
\hline 13 & 126.7 & & 125.2 & & 123.8 & & 124.9 & \\
\hline 14 & 109.4 & $6.21 \mathrm{br} \mathrm{s}$ & 109.9 & $6.48 \mathrm{br} \mathrm{s}$ & 108.9 & $6.42(\mathrm{t}, 1.6)$ & 108.4 & $6.39(\mathrm{dd}, 2.0 ; 0.7)$ \\
\hline 15 & 144.0 & 7.16 br s & 144.9 & $7.47 \mathrm{br} \mathrm{s}$ & 143.5 & 7.48 br s & 143.6 & $7.40(\mathrm{dd}, 2.0 ; 1.4)$ \\
\hline 16 & 139.9 & $7.15 \mathrm{br} \mathrm{s}$ & 141.0 & $7.53 \mathrm{br} \mathrm{s}$ & 139.5 & $7.42(\mathrm{t}, 1.6)$ & 139.4 & 7.43 br s \\
\hline 17 & 171.0 & & 175.3 & & 175.8 & & 174.5 & \\
\hline 18 & 170.6 & & 177.3 & & 173.7 & & 175.8 & \\
\hline 19 & 16.8 & $1.13 \mathrm{~s}$ & 16.1 & $1.16 \mathrm{~s}$ & 24.2 & $1.34 \mathrm{~s}$ & 20.3 & $1.25 \mathrm{~s}$ \\
\hline 20 & 15.6 & $0.80 \mathrm{~s}$ & 25.8 & $1.39 \mathrm{~s}$ & 14.6 & $1.01 \mathrm{~s}$ & 33.8 & $1.11 \mathrm{~s}$ \\
\hline $\mathrm{OMe}$ & 52.4 & $3.49 \mathrm{~s}$ & 54.8 & $3.85 \mathrm{~s}$ & 53.2 & $3.70 \mathrm{~s}$ & 52.8 & $3.79 \mathrm{~s}$ \\
\hline$\underline{\mathrm{MeCO}}$ & 21.4 & $1.80 \mathrm{~s}$ & - & - & - & - & - & - \\
\hline$\overline{\mathrm{MeCO}}$ & 170.3 & - & - & - & - & - & - & - \\
\hline
\end{tabular}

${ }^{a}$ Assignments made on the basis of DEPT, COSY, NOESY, HMQC, and HMBC for $\mathbf{1}$ and DEPT, COSY, HMQC, and HMBC for 2; ${ }^{\text {b Signals may }}$ be interchangeable.

3); $\delta_{\mathrm{C}} 131.4(\mathrm{C}-2)$ and 129.7 (C-3)], two angular methyl groups $\left[\delta_{\mathrm{H}} 1.16(\mathrm{~s}, \mathrm{Me}-19)\right.$ and $1.39(\mathrm{~s}, \mathrm{Me}-20) ; \delta_{\mathrm{C}} 16.1$ (Me-19) and $25.8(\mathrm{Me}-20)]$, a carbonyl methyl ester $\left[\delta_{\mathrm{H}}\right.$ $3.85(\mathrm{~s}) ; \delta_{\mathrm{C}} 54.8(\mathrm{OMe})$ and $\left.177.3(\mathrm{C}-18)\right]$, a $\delta$-lactone $\left[\delta_{\mathrm{H}}\right.$ $5.31(\mathrm{dd}, J 5.5$ and $13.5 \mathrm{~Hz}) ; \delta_{\mathrm{C}} 71.2$ and 175.3 ], besides signals for two methines, four methylenes, and three nonhydrogenated carbons. The ${ }^{13} \mathrm{C}$ NMR spectra (CPD, DEPT and HMQC) displayed 21 carbon signals assignable to three methyls, four methylenes, eight methines, and five non-hydrogenated carbons. In the general mode, the NMR spectral data of $\mathbf{2}$ were closely similar to those of $\mathbf{1}$, except for the absence of the signals for an acetyl group, which was replaced by a hydroxyl group [1: $\delta_{\mathrm{C}} 87.8(\mathrm{C}-4)$ and $\mathbf{2}$ : $\delta_{\mathrm{C}} 82.1(\mathrm{C}-4)$ ], suggesting that 2 may be the 4-deacetylderivative. In fact, the deacetylation to yield the hydroxyl group caused the expected upfield shift of the C-4 $(\Delta \delta=$ $-5.7 \mathrm{ppm})$. Extensive use of NMR techniques, including ${ }^{1} \mathrm{H}-{ }^{1} \mathrm{H}$ COSY, HMQC, and HMBC (Figure 1), supported the unambiguous assignments of all ${ }^{1} \mathrm{H}$ and ${ }^{13} \mathrm{C}$ shift values (Table 1).

Although some of the NMR assignments of cordatin (7) ${ }^{12}$ must be revised, comparison of the ${ }^{13} \mathrm{C}$ NMR data of 2 with those of $\mathbf{7}$ were very similar, except for the chemical shifts of the C-3 $\left(2: \delta_{\mathrm{C}} 129.7 ; 7: \delta_{\mathrm{C}} 123.2\right.$, value interchanged in the paper with C-2) and C-18 (2: $\delta_{C} 177.3$; 7: $\delta_{\mathrm{C}}$ 173.7), suggesting that two compounds are epimers at C-4. However, when compared with those of epicordatine $(\mathbf{8}),{ }^{13}$ which possess $\mathrm{A} / \mathrm{B}$ and $\mathrm{B} / \mathrm{C}$ cis ring junctions, revealed that the two compounds are not identical since differences in the chemical shifts of the several carbons were observed (Table 1). Therefore, compound 2 was proposed to be the $(5 \mathrm{R}, 8 \mathrm{~S}, 9 \mathrm{R}, 10 \mathrm{R})-4 \mathrm{~S}$ hydroxy-15,16-epoxy-neo-cleroda-2,13(16),14-trien17,12S-olide-18-oate methyl, a clerodane diterpene with $\mathrm{A} / \mathrm{B}$ trans and $\mathrm{B} / \mathrm{C}$ cis ring junctions, named here crotobrasilin B.

Several structurally distinct clerodane-type diterpenes have been found in Croton species, but to our knowledge, this is the first report of the occurrence of crotobrasilin A and crotobrasilin B from natural sources.

The IR, ${ }^{1} \mathrm{H}$ and ${ }^{13} \mathrm{C}$ NMR spectral data for casticin (3),${ }^{14,15}$ peduletin (4), ${ }^{14}$ artemetin $(5)^{16}$ and chrysosplenol$\mathrm{D}(\mathbf{6})^{16}$ were in accordance with those reported in the literature. Several structural types of flavonoids have been 
reported from Croton species. ${ }^{3-6}$ However, all the 3-methoxyflavones related in this work are described for the first time in this genus.

\section{Experimental}

\section{Instrumental and chromatography materials}

The melting point was measured using an MQAPF302 apparatus and is uncorrected. Optical rotation was measured on a Perkin-Elmer 341 polarimeter. The NMR spectra were recorded either on a Bruker DRX-500 or Mercury-Varian 200 operating at 500 and $200 \mathrm{MHz}$, respectively, for ${ }^{1} \mathrm{H}$ and 125 and $50.3 \mathrm{MHz}$, respectively, for ${ }^{13} \mathrm{C}$, in $\mathrm{C}_{6} \mathrm{D}_{6}$ or $\mathrm{CDCl}_{3}$, and DMSO- $d_{6}$ solutions with TMS as internal standard. IR spectra were obtained on a FT-IR 1750 Perkin-Elmer spectrometer. EIMS were measured at $70 \mathrm{eV}$ on a HP 5990/5988A spectrometer. Silica gel (70-230 and 230-400 mesh, Merck) and Sephadex LH20 (Pharmacia) were used for column chromatography separations.

\section{Plant material}

The leaves and stems of C. brasiliensis Mull. Arg. (syn. C. polyandrus Spreng) were collected in November 1999, in the Área de Proteção Ambiental de Santa Rita (Mucuri), Marechal Deodoro, Alagoas, Brazil, and was identified by Rosangela P. de Lyra Lemos of the Departamento de Botânica do Instituto do Meio Ambiente do Estado de Alagoas (IMA-AL), where a voucher specimen was deposited (MAC-10752).

\section{Extraction and isolation of the constituents}

The air-dried and powdered leaves (1300 g) and stems (900 g) were extracted with acetone followed by $90 \%$ EtOH at room temperature. The crude extracts [leaves: acetone (142.8 g); stems: acetone (23.9 g) and EtOH (16.2 g)] were suspended in $\mathrm{MeOH}-\mathrm{H}_{2} \mathrm{O}(3: 2)$ solution and extracted successively with $\mathrm{C}_{6} \mathrm{H}_{14}, \mathrm{CH}_{2} \mathrm{Cl}_{2}$ and EtOAc. The $\mathrm{CH}_{2} \mathrm{Cl}_{2}$ residue of the acetone extract from leaves $(16.7 \mathrm{~g})$ was filtrated on silica gel with $\mathrm{C}_{6} \mathrm{H}_{14}-\mathrm{CH}_{2} \mathrm{Cl}_{2} 1: 1$ (7.3 g, A), $\mathrm{CH}_{2} \mathrm{Cl}_{2}(0.9 \mathrm{~g}, \mathrm{~B}), \mathrm{CH}_{2} \mathrm{Cl}_{2}$-EtOAc 1:1 (2.9 g, C), EtOAc (1.06 g, D) and $\mathrm{MeOH}(1.51 \mathrm{~g}, \mathrm{E})$. Fractions A (7.3 $\mathrm{g})$, B (0.9 g) and C (2.9 g) were chromatographed on silica gel column using $\mathrm{C}_{6} \mathrm{H}_{14}$ with increasing amounts of $\mathrm{CH}_{2} \mathrm{Cl}_{2}$. The subfractions obtained after gel permeation on Sephadex LH-20 (MeOH) and successive recrystallizations from $\mathrm{MeOH}$ afforded $\mathbf{1}$ (33 mg), 3 (21 $\mathrm{mg}), \mathbf{4}$ (40 mg), and $\mathbf{5}$ (108 mg).
The $\mathrm{CH}_{2} \mathrm{Cl}_{2}$ residues from stems $(5.0 \mathrm{~g})$ were submitted to silica gel filtration with $\mathrm{C}_{6} \mathrm{H}_{14}-\mathrm{CH}_{2} \mathrm{Cl}_{2} 1: 1(1.2 \mathrm{~g}, \mathrm{~A})$, $\mathrm{CH}_{2} \mathrm{Cl}_{2}(1.21 \mathrm{~g}, \mathrm{~B}), \mathrm{CH}_{2} \mathrm{Cl}_{2}$-EtOAc 9:1 (0.94 g, C), EtOAc (1.35 g, D) and $\mathrm{MeOH}(0.08 \mathrm{~g}, \mathrm{E})$. Fraction A (1.2 g), after gel permeation on Sephadex LH-20 (MeOH) and successive recrystallizations from $\mathrm{MeOH}$, afforded a mixture 2.5:1 containing 1 and 2 (16 mg), and 6 (18 mg).

(5R,8R,9R,10R)-4R-Acetoxy-15,16-epoxy-neo-cleroda2,13(16),14-trien-17,12S-olide-18-oate methyl (Crotobrasilin $A, \mathbf{1}$ )

White amorphous powder, mp 198.5-201.4 ${ }^{\circ} \mathrm{C} ;[\alpha]_{\mathrm{D}}^{20}+$ $25.1^{\circ}\left(\mathrm{CHCl}_{3}, c 0.0052\right)$. IR $(\mathrm{KBr}) v_{\max } / \mathrm{cm}^{-1}: 2953,1734$, 1665, 1490, 1450, 1374, 1267, 1134, 1076, 1020, 876, 816, 785; EIMS, $70 \mathrm{eV} \mathrm{m/z} \mathrm{(rel.} \mathrm{int.):} 416$ [M] (2), 401 $\left(\mathrm{M}-\mathrm{CH}_{3}, 2\right), 357$ (M-OAc, 10), $374\left(\mathrm{M}-\mathrm{C}_{2} \mathrm{H}_{2} \mathrm{O}, 3\right), 342$ (M-C $\left.\mathrm{H}_{6} \mathrm{O}_{2}, 2\right), 315$ (100), 297 (5), 247 (3), 203 (10), 153 (20), 121 (10), 105 (21), 91 (22); ${ }^{1} \mathrm{H}(500 \mathrm{MHz})$ and ${ }^{13} \mathrm{C}$ (125 MHz, $\mathrm{C}_{6} \mathrm{D}_{6}$ ) NMR spectra (see Table 1).

(5R,8S,9R,10R)-4S-Hydroxy-15,16-epoxy-neo-cleroda2,13(16),14-trien-17,12S-olide-18-oate methyl (Crotobrasilin $B, 2)$.

Yellowish oil. ${ }^{1} \mathrm{H}(500 \mathrm{MHz})$ and ${ }^{13} \mathrm{C}\left(125 \mathrm{MHz}, \mathrm{CDCl}_{3}\right)$ NMR data are given in Table 1.

\section{Acknowledgments}

The authors are grateful to FAPEAL, CNPq, and Ministério da Ciência e Tecnologia-Instituto do Milênio do Semi-Árido (MCT-IMSEAR) for financial support and research fellowships, to Vicente Carlos C. de Oliveira (LTF, Universidade Federal da Paraíba), Daniel Esdras de Andrade Uchoa (CENAUREMN, Universidade Federal do Ceará), and Dr Daniela F. Navarro (Depto Química, Universidade Federal de Pernambuco) for the NMR and MS spectra.

\section{References}

1. Schultz, A.R.H.; Introdução à Botânica Sistemática, $4^{\mathrm{a}}$ ed., Editora da Universidade: Porto Alegre, 1984.

2. Farnsworth, N.R.; Blomster, R.N.; Messmer, W.M.; King, J.C.; Persinos, G.J.; Wilkes, J.D.; Lloydia 1969, 32, 1.

3. Peres, M.T.L.P.; Monache, F.D.; Cruz, A.B.; Pizzolatti, M.G.; Yunes, R.A.; J. Ethnopharmacol. 1997, 56, 223.

4. Maciel, M.A.M.; Pinto, A.C.; Arruda, A.C.; Pamplona, S.G.S.R.; Vanderlinde, F.A.; Lapa, A.J.; Echevarria, A., Grynberg, N.F.; Colus, I.M.S.; Farias, R.A.F.; Costa, A.M.L.; Rao, V.S.N.; J. Ethnopharmacol. 2000, 70, 41. 
5. Graikou, K.; Aligiannis, N.; Skaltsounis, A.L.; Chinou, I.; Michel, S.; Tillequin, F.; Litaudon, M.; J. Nat. Prod. 2004, 67, 685.

6. Guadarrama, A.B.A.; Rios, M.Y.; J. Nat. Prod. 2004, 67, 914.

7. Peres, M.T.L.P.; Monache, F.D.; Pizzolatti, M.G.; Santos, A.R.S.; Beirith, A.; Calixto, J.B.; Yunes, R.A.; Phytother. Res. 1998, 12, 209.

8. Barbosa, P.R.; Fascio, M.; Martins, D.; Guedes, M.L.S.; Roque, N.F.; Biochem. Syst. Ecol. 2003, 31, 307.

9. McChesney, J.D.; Silveira, E.R.; Fitoterapia 1990, 61, 172.

10. El Mekkawy, S.; Meselhy, M.R.; Nakamura, N.; Hattori, M.; Kawahata, T.; Otake, T.; Phytochemistry 2000, 53, 457.

11. Giang, P. M.; Son, P.T.; Lee, J.J.; Otsuka, H.; Chem. Pharm. Bull. 2004, 52, 879.
12. Dadoun, H.; Mueller, A.H.; Cesário, M.; Guilhem, J.; Pascard, C.; Phytochemistry 1987, 26, 2108.

13. Mambu, L.; Ramanandraibe, V.; Martin, M.T.; Blond, A.; Grellier, P.; Frappier, F.; Planta Med. 2002, 68, 377.

14. Wang, Y.; Hamburger, M.; Gueho, J.; Hostettemann, K.; Phytochemistry 1989, 28, 2323.

15. Sharaf, M.; Mansour, R.M.A.; Saleh, N.A.N.; Biochem. Syst. Ecol. 1992, 20, 443.

16. Agrawal, P.K.; Thakur, R.S.; Bansal, M.C. In Carbon-13 NMR of Flavonoids; Agrawal, P.K., ed., Elsevier: New York, 1989, ch. 3 .

Received: August 15, 2005 Published on the web: October 11, 2005 